\title{
Factors Influencing Bankers' Intention to Adopt Green Finance in Pakistan
}

\section{Owais Shafique ${ }^{a}$, Arslan Majeed ${ }^{b}$}

${ }^{a}$ Assistant Professor, Department of Islamic and Conventional Banking, School of Business, Management and Administrative Sciences, The Islamia University of Bahawalpur, Pakistan.

Email: dr.owais.shafique@gmail.com,owais.shafique@iub.edu.pk

${ }^{\mathrm{b}}$ MS Scholar, School of Business, Management and Administrative Sciences, The Islamia University of Bahawalpur, Pakistan.

Email: arsalsaeen51@gmail.com

\begin{tabular}{ll}
\hline ARTICLE DETAILS & ABSTRACT \\
\hline History: & The purpose of this study is to investigate factors that influence \\
Accepted 18 Nov 2020 & bankers' intention to adopt green banking in Pakistan. Green \\
Available Online 31 Dec 2020 & banking refers to providing environment-friendly banking \\
& services and financial products through environment-friendly \\
Keywords: & banking operations and infrastructure. It can be referred to as \\
Green Banking, Policy & sustainable lending and depository products and bank's services \\
Guidelines, Attitude towards & through sustainable banking operations and infrastructure. The \\
usage, Central Bank & data for this study was collected from 25o respondents through a \\
Regulations, Management & structured questionnaire. Data analysis was performed using the \\
Commitment and Support, & partial least squares (PLS) approach. The study's findings \\
Pakistan. & indicate that Policy Guidelines, Attitude towards usage, Central \\
& Bank Regulations, and Management commitment and support \\
JEL Classification: & influence bankers' intention to adopt a green banking in Pakistan. \\
G24, G32, H63, H69 & This research will help the State bank of Pakistan and bank's \\
& senior management to identify the key factors influencing the \\
DoI: 10.47067/reads.v6i4.277 & adoption of green banking in Pakistan.
\end{tabular}

(C) 2020 The authors. Published by SPCRD Global Publishing. This is an open access article under the Creative Commons Attribution-

NonCommercial 4.0

Corresponding author's email address: owais.shafique@iub.edu.pk

\section{Introduction}

Many developing countries have introduced the perception of green banking has been introduced by many developing countries in recent years to obtain economic growth and development because ecofriendly protection conditions are traded off. To bear losses due to the 2008 global financial crisis, developing countries felt a need to modernize their financial systems. Many researchers emphasize the significance of green finance. They say green finance encourages ecological practices and reduces the carbon footprint of banking activities. 


\section{Review of Economics and Development Studies, Vol. 6 (4) 2020, $773-785$}

Pakistan, India, and Bangladesh are surrounded by the most vulnerable countries in front of the impacts of climate transform. Therefore, these countries have distress about eco-friendly deprivation. Pakistan being a developing country is agony from vast eco-friendly, economic, political, and social problems, and these factors needed to be painstaking for the growth of this country. Various developing countries have adopted the notion of Green banking residential into the western world. It means the ecosystem -receptive banking and it also states to the modest banking or sustainable banking.

Green Bank gives many useful solutions for many surrounding problems like weather change, deforestation, excretion of carbon dioxide, and biodiversity loss. It also points out and produces many options for the benefits of the customer and also for surrounding survival. It also needs to give finance to those parts that emphasize many protection activities of the environment. There are many obstacles to the acceptance of Green Banking in developing countries. For its acceptance in 25 developing countries, IFC surveyed spectrum of Green Banking. There are a series of obstacles to adopting Green Banking by IFC, which stems from the similarity of most of the countries studied, including the lack of specific measurement standards for Green Banking. This is particular for a country in its individual context, because there is a lack of awareness regarding the acceptance of Green Banking in operations of banks and among the stakeholders in the bakery sector.

There are also some weaknesses in developing countries like a lack of support from the government, the problem of attraction of clients to energy projects or exercise of emission reduction, the problem of stoppage of immediate lending to the typical high pollutants and emission sectors like the oil sector and coal power stations, not enough leaders in Green Banking, lack of knowledge of business cases and high acceptance of the cost of some specific green initiatives like green building and green information technology.

In recent times there is limited research available in the field of Green Banking with the current value of the banking sector in any country's betterment relating to the environment (Ahmad et al., 2013). There is very limited research available in academic literature for the adoption of Green Banking. So, there is a need to explore the determinants of adoption or acceptance of green banking from a theoretical perspective in developing countries.

Much knowledge is available related to Green banking, particularly in the emerging countries, foremost to unproductive controlling mechanism and measurement structure within the banking industry. Due to limited literature, it is challenging for policymakers and industry to understand the concept that individual banks can play a role in qualifying climate change and facilitating the transition to a low-carbon economy. For the facility of Green banking, Banks have insufficient data and information. This becomes managed to evidence of a research contribution and demand for improved research on Green Banking adoption in the developing countries (Ahmad et al., 2013).

The primary focus of this research is to find the relevant factors or variables that are required to adopt green banking. To understand, create, and explain why people accept or reject Green banking, investigator have developed and used too many models to understand the behavioral intension of taking on (Alshibly, 2011). Here, this study attempts to analyze the factors influencing the behavioral intension of a prospective user to adopt Green banking in the Pakistan banking industry. 


\section{Literature Review}

Environmental concerns are gaining momentum globally. Human activities are now proven to be the prime cause of environmental degradation, which is extremely harmful for all living beings (Masood et al., 2015). A key determinant in GDP growth of a nation is private investment, but its role in the process of environmental degradation has been vastly ignored (Parveen et al., 2020). FDI, energy consumption and population significantly increase $\mathrm{CO}_{2}$ emissions (Chaudhry et al., 2020). Macroeconomic variables such as economic growth, urbanization and industrialization are linked with $\mathrm{CO} 2$ emissions (Parveen et al., 2019). Hygenic and healthy environment is necessary for all living beings and society as it enriches their quality of life (M. Z. U. Khan et al., 2019).

The banking sector's solution to these environmental concerns is Green Banking. The term Green is used for a financial institute like Green banking, which mainly expresses the liability of banks towards the external conditions of surroundings and the function of the environment in the process of business (Bai, 2011).

The green bank grants all banks permission to manage their money according to their principles; they have the right to use their assets and capital per the requirement. Green banking allows the banks to use their money the best way and generates maximum profit through their activities without reducing the level of material comfort of people and the wellbeing of the environment. It promotes successful performance, reduces the difficulties in a way to achieve success, and helps for the advancement and development of the banking sector (Goyal \& Joahi, 2011). Bhardwaj and Malhotra (2013) declared the fact that operations of the banks might not cause the decaying of the environment, but the customers who dealt with the bank may be involved in such activities that are not suitable for the environment and damaged the environment in the future.

At the time of making an investment or financing any project and lending the money to the client, banks assure their liability towards the environment and realize their responsibility regarding the society (Thombre, 2011). Banks can control the situation from an industrial side with which they cause damage to the environment by providing official requirements of funds on the condition that their administrative activities contribute to the environment directly. The use of suitable technologies to handle particular situations and administrations direct them to realize their responsibility towards the environment and society (Masukujjaman \& Aktar, 2014).

In this way, banks can treat their moral duties by paying out their money to those institutions that relate their operations with favorable conditions of the environment (Goyal \& Joahi, 2011). Banks can also do this by modifying the internal conditions of their systems as they can replenish their energy supplies, automatic process, and significant minimal usage of carbon (Millat et al., 2012).

Nowadays, banks must be sure regarding their responsibility toward the environment for the sustainable financial reward and success because a recent study of Javelin Strategy and Research estimates that about 53\% of customers want to belong to the banks that have the power to originate the positive actions for the environment and society (Green Wiki, 2015). The top five Romanian banks confirm this attention by citing them as a better-rated bank because they invest their assets in projects that are both socially and environmentally responsible. 
Review of Economics and Development Studies, Vol. 6 (4) 2020, $773-785$

Now due to awareness, customers require such types of financial products and investment opportunities that may have positive effects on the environment because everyone has an adequate knowledge about right actions with a positive impact on the environment to become a responsible Citizen. Due to customer preference, banks move toward green banking as no bank wants to lose any client (Munchow, 2011).

It is also interesting that the investor of the stock market also resists to anti-eco-friendly activities from the parent company. The investor stands in opposition for those companies which show no concern toward the environment and the society. This shows the level of feelings and excitement of the market and demand for financial sustainability of institutions (Rehman, 2015).

These days, it is necessary to disclose the facts that are necessary for the maintenances of improvement and advancement in economies that are coming to mature in the future; they need to stimulate the discussion of the fundamental rules regarding the environment (Raluca, 2013). Banks can take the initiative through preliminary steps toward the concern about the environment and make their institutes trustworthy.

In the Earth Summit 1992, the United Nations Environment Program (UNEP) moved towards positive development of the environment and maintaining this development by confirming the slandered of influence of society. Banks can achieve this by maintaining the contact of banks with UNEP, and with the help of each other, they can achieve a noticeable achievement. To create more stability, another unit was introduced by IFC in 1991. This unit reviewed all the projects and checked their effects on the environment and society.

The IFC launched the Equator Principle with the collaboration of a group of banks in 2003, some 46 financial institutions from 16 countries consider it to be rules, and now more than 100 countries are interconnected with the IFC. IFC, along with the Financial Times, also initiated Sustainable Banking Award since 2006. The number of banks joining the IFC is increasing day by day. In the previous year, 48 banks from 28 countries were collaborating. The International Organization is taking another initiative for Standardization 14000, which includes a large number of standards relating to the environment and associated enterprises acting following these standards.

In this race, European banks are moving quickly and are behaving as leaders in the international market to maintain the concept of green banking concerning all other continents and are rapidly developing towards a leading environment as a rare philosophy. Rosenfeld and Tchapi (2007) referred to two central banks in Sweden and found that they had a clear understanding of the progress of global green banking and were attentive to all environmentally friendly actions.

In the United States, socially responsible investment (SRI) funds have been very well received, with SRI assets amounting to \$2.29 trillion in 2005 (Starogiannis, 2006). Going further, the Dutch government requested banks to maintain such plans and operations that have a positive impact on the environment towards achieving long-lasting development. Recent research shows that Indian banks also focus on the importance of eco-friendly factors and pay special attention to those projects which have positively contributed to helping the environment. The first initiative was taken by the State Bank of India (SBI), it is going to finance in the windmills that generate green power with zero harmful 
Review of Economics and Development Studies, Vol. 6 (4) 2020, 773 - 785

factors on the environment and some other banks also perform their duties toward green banking by proving different environment as friendly products (Nath et al., 2014). The purpose of green banking in the market of India along with a large number of difficulties faced by the bank just like a loss to peers, lack of central banks' mandate, lack of interest of customers and investors, complicated reporting structure, inadequate funds for training, and lack of skilled force of available workers, etc. It is importent to note here that, human capital is an irreplaceable resource for the modern organizations because they posess skills, experience and knowledge skill, making it a key factor for the firm's success in the knowledge economy of this era (Aleem \& Bowra, 2020).

Less developed countries like Bangladesh can achieve financial sustainability through the occurrence of strong rebounding with the essential factor of surrounding that is environment development. In the banks of Bangladesh, with the basic operation of banking, they also pay attention toto other internal processes in which a considerable quantity of carbon is discharged like massive use of electricity due to the usage of lights, air-conditioning, and other electrical equipment (Rahman et al., 2013).

Bangladesh Bank takes preventive measures and follow the direction toward a positive behavior regarding the environment and considering the importance and value of circumstances without damaging the social elements (M. T. A. Khan, 2012). From time to time, the central bank of Bangladesh addressed to other conventional banks to adopt the strategies as per instruction of green strategic planning for 2013 and beyond.

Banks are liable to their activities. Therefore, they try to convert their system into a green banking system and do practice green financing. As Millat et al. (2012) reported that all the banks in Bangladesh had received regular directions to make efforts toward green banking, and their policies have the power to convey the importance of green banking in all investment and lending operations. In this way, they resolve the eco-friendly problems and combine them with national eco-friendly rules and acts. According to a recent study (Ullah, 2013), with the collaboration of GBG, banks of Bangladesh spread their technical assistance at a broad scale. Four banks are included in this study. This study has proven that state-owned banks have zero compliance with the GBG, continue to finance harmful projects, introduced no advancement in the field of paperless banking. On the other hand, private banks show more progress in this field.

Pakistan was late for green financial activities, among other issues, in 2017. Banks and DFIs are already in the process of establishing an SBP strategy platform. The green banking cycle is long, but it will pay to address eco-friendly issues in the country. India and China undergo improvement in developing and implementing these measures under the green finance policies. Although the rest of the countries are a long way in improving and implementing the green economic exercises as they have many concerns in applying these measures, e.g., banks have limited resources to assess the borrower under welcoming ecological conditions, lack of accountability, banking people are not trained, borrowers are unaware of adapting measures necessary to perceive eco-friendly measures.

\section{HYPOTHESIS DEVELOPMENT}

\subsection{Policy Guidelines (PG)}

The extent with which a character assumes that a program will assist in achieving job performance enhancements. Human resources of banks have realized that executing green banking will 
Review of Economics and Development Studies, Vol. 6 (4) 2020, 773 - 785

help them in realizing success and efficacy in their errands. Pieces of evidence in the past show that performance expectancy is the strongest analyst and more applicable in implementing any technologyrelated service (Alwahaishi \& Snášel, 2013). Reliability of green banking technologies can only be expressed in how far it can satisfy the needs of customers. If employees think that it can be , more accessible,more comfortable and faster to operate with electronic banking systems, they are more inclined to do so. Hence, the suggestion is the following.

H1: Policy Guidelines significantly affects bankers' intention to use green banking technologies.

\subsection{Attitude towards usage (ATU)}

Management commitment and support (MCS) refers to the involvement, passion, inspiration, and back-up provided by management towards the receipt of green banking. Top management claims to be one of the best predictors of the adoption of Green Banking by the secretariats. In order to persuade other directorial leaders to embrace the latest technology revolution or to employ it in operation, senior managers in any company are likely to have a critical role to play. Additionally, they also commit resources to its adoption (Ifinedo, 2011).

H2: Attitude towards usage (ATU) will have a significant influence on users' intention to adopt green banking (IAGB).

\subsection{Central Bank Regulations (CBR)}

The approval of the national central bank is now one of the principal factors behind the growth of green banks in Bangladesh. The shortage of voluntary inclusion in this project faced a constructive fight from the leaders and the trained bank workers. Indeed, green banking affects the operating climate, and the provision of alternative financial facilities within the framework of green finance contributes to damages such as structure, rapid implementation of banking policies and initiatives, discrepancies between management and banks and banking operators, etc. (Hossain et al., 2016). Green banking arrangement may also entail specific tasks for the bankers as they are expected to send weekly reports describing the green banking tricks of their banks (Rehman, 2015). As such, the central bank strategy can sway bankers' perception of green banking in this study. Hence, the next suggestion is the following:

H3: Central bank regulations significantly affect bankers' intention to use green banking technologies.

\subsection{Management commitment and support (MCS)}

Management commitment and support (MCS) refers to taking part, interest, impetus, and backup provided by management towards the taking of green banking. In detail, top management claims to be one of the best predictors of organizational implementation of green banking. If top managers in a company recognize the value of innovative technology or the usage of business innovations, they continue to play a crucial role in convincing other organization leaders to adopt them(Ifinedo, 2011). Past studies have shown that MCS is a significant factor impacting green banking intentions; for example, Ramdani et al. (2009) on endeavor system and Ifinedo (2011) on internet getting here, it has been anticipated that:

H4: Management commitment and support will have a significant influence on the intension to adopt green banking (IAGB). 


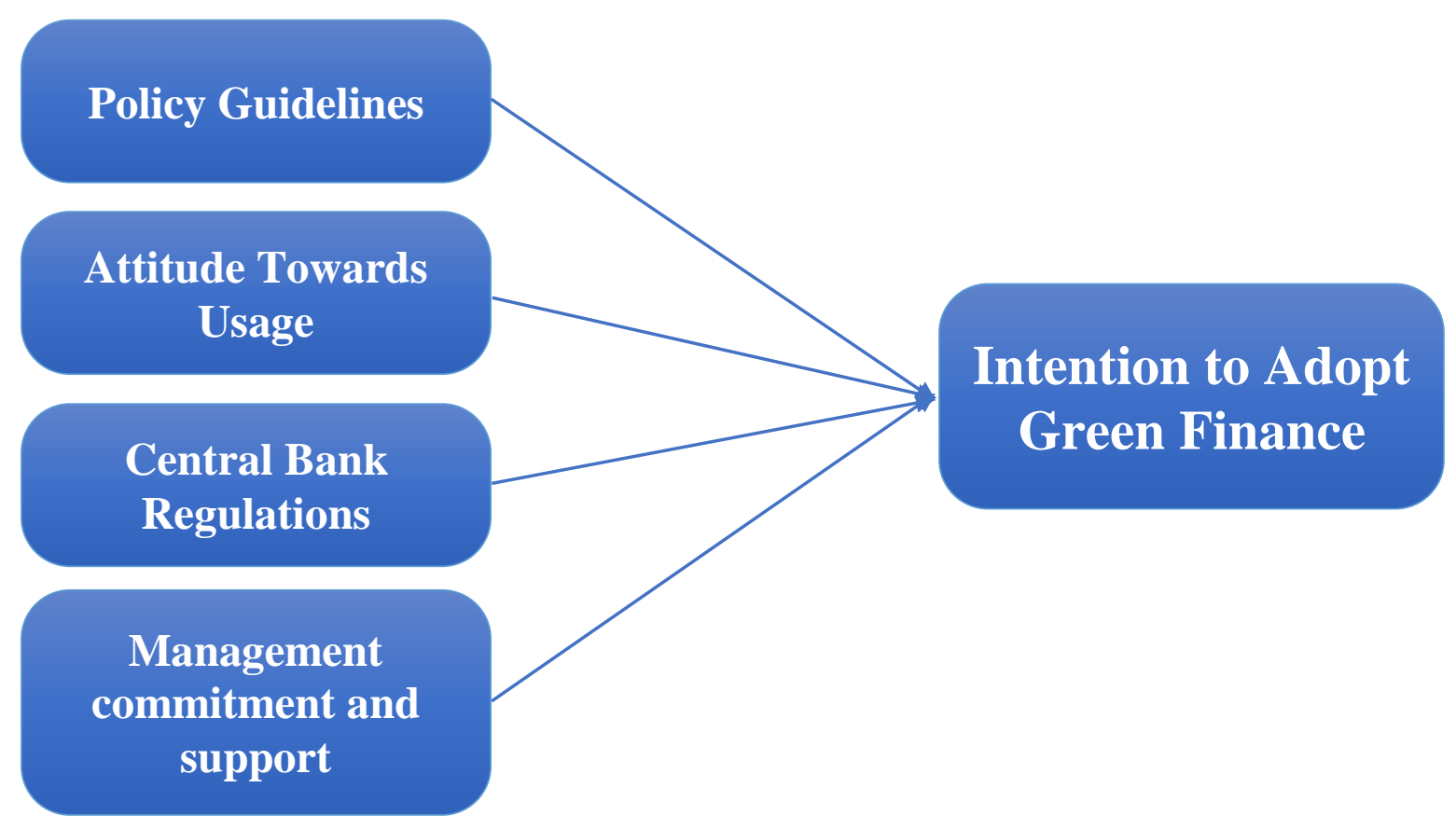

Figure 1: Conceptual Framework

\section{Research Methodology}

Due to the relatively small sample size, Structural Equation Modeling (SEM) based on Partial Least Squares (PLS) was adopted for the psychiatric therapy of the data. PLS was used for the reason that it makes nominal demands on the statistical distributions, sample size, and quantity balances, and as this study was groping in nature, it is a superior tool to explain the data. The survey instrument, the questionnaire, has been developed based on various previous studies (Ifinedo, 2011; Martín et al., 2012). A total of 57 questions were used to prepare the interviewers. The variable was measured on a fivepoint Likert scale, where "1" means "Strongly disagree" and "5" means "Strongly agree." In total, 250 questionnaires were distributed among the employees of Pakistan's Bank. This study, adopts the twostep draw near advocated by Anderson (1998). A detailed measurement of the measurement model at the item level and higher-order level were done in the first step. A psychotherapy of the posited structural relationships was taken to the next stage. The PLS path approach model was adopted to examine both the quantity and the structural model. Part least square (PLS) is an ingenious statistical dropping technique that is ideally suited to the psychiatry of genomic and proteomic data. Version 2.0 of intelligent PLS was used for the analysis.

The model has been veteran for convergent force and discriminant weight for assessing measurement mock-up. The examination of convergent validity includes item consistency and internal consistency by measuring Merged Reliability (CR) and Normal Variance Extracted (AVE). At the level of brands and articles, tartan has been the converging force. To test the structural model, the path coefficient, the value of the t-statistics, and the explanatory power of the independent variables were tested. 


\section{Data Analysis and Interpretation}

\subsection{Results of the Model Tests Using (PLS-SEM)}

The measurement model for this study was at first put through confirmatory factor analysis and later it was tested for convergent, and discriminant validity and reliability. Moreover, SEM model built in SmartPLS with the PLS algorithem results is presented in Figure 2.

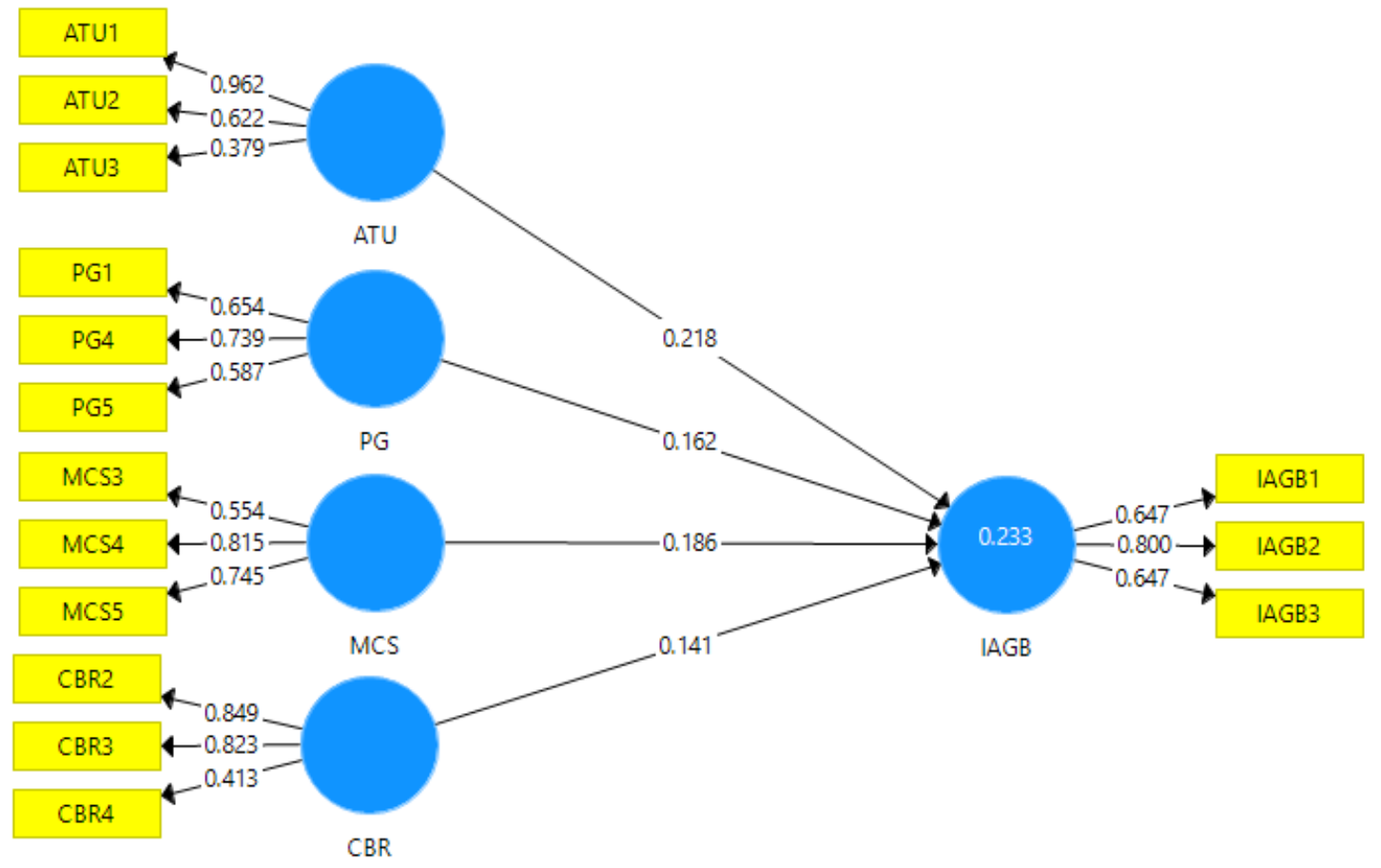

Figure 2: SEM Model with all latent constructs and respective measurement items

\subsection{Evaluation of the Structured Model}

In the model, the items representing the reflective constructs must exhibit convergent, and discriminant validity and internal/composite reliability (Hair et al., 2014). These tests were performed by executing the PLS PLS algorithm using default settings as suggested by Hair et al. (2014) - i.e. 300 interactions, a stop criterion of 7 and case-wise deletion of missing values. Table 1 presents the internal/composite reliability for the measurement model:

\begin{tabular}{|l|c|c|c|c|}
\hline \multicolumn{5}{|c|}{ Table 1: Internal/Composite Reliability } \\
\hline Items & $\begin{array}{c}\text { Cronbach's } \\
\text { Alpha }\end{array}$ & RHO_A & $\begin{array}{c}\text { Composite } \\
\text { Reliability }\end{array}$ & $\begin{array}{c}\text { Average Variance } \\
\text { Extracted (AVE) }\end{array}$ \\
\hline ATU & 0.752 & 1.108 & 0.714 & 0.586 \\
\hline CBR & 0.810 & 1.640 & 0.752 & 0.523 \\
\hline IAGB & 0.753 & 1.517 & 0.742 & 0.592 \\
\hline MCS & 0.710 & 1.558 & 0.752 & 0.509 \\
\hline PG & 0.805 & 1.379 & 0.787 & 0.539 \\
\hline
\end{tabular}


Review of Economics and Development Studies, Vol. 6 (4) 2020, $773-785$

\subsection{Discriminant Validity}

The degree to which a constructed variable is changed from the other hypotheses in the model is called discriminant validity (Chin et al., 2003). It examines the inimitability of every hypothesis to confirm that it is not simultaneous with another construct (Hair et al., 2014). Hair et al. (2014) claims that there are 2 different gauges to access discriminant validity:

- Item cross-loadings: It examines the outer loadings of indicators on their theoretically intended constructs.

- The Fornell-Larcker criterion: It is viewed conventional measure of evaluating discriminant legitimacy.

\subsection{Cross-loadings}

To establish discriminant rationality, the piling of each dimension item on its agreeing construct must be more substantial as of its loading within one construct (Hair et al., 2014). The dimensional items of a hypothesis only measure their concept and not any others.

\begin{tabular}{|c|c|c|c|c|c|}
\hline \multicolumn{6}{|c|}{ Table 2: Cross-loadings } \\
\hline & ATU & CBR & IAGB & MCS & PG \\
\hline ATU1 & 0.962 & 0.315 & 0.380 & 0.244 & 0.242 \\
\hline ATU2 & 0.622 & 0.301 & 0.135 & 0.196 & 0.034 \\
\hline ATU3 & 0.379 & 0.188 & 0.031 & 0.353 & -0.054 \\
\hline CBR2 & 0.253 & 0.849 & 0.307 & 0.330 & 0.262 \\
\hline $\mathrm{CBR}_{3}$ & 0.415 & 0.823 & 0.273 & 0.391 & 0.159 \\
\hline CBR4 & 0.010 & 0.413 & 0.118 & 0.254 & 0.048 \\
\hline IAGB1 & 0.172 & 0.163 & 0.647 & 0.248 & 0.141 \\
\hline IAGB2 & 0.322 & 0.304 & 0.800 & 0.265 & 0.252 \\
\hline IAGB3 & 0.227 & 0.230 & 0.647 & 0.199 & 0.162 \\
\hline MCS3 & 0.272 & 0.421 & 0.167 & 0.554 & 0.146 \\
\hline MCS4 & 0.217 & 0.299 & 0.289 & 0.815 & 0.170 \\
\hline MCS5 & 0.147 & 0.289 & 0.249 & 0.745 & 0.055 \\
\hline PG1 & 0.089 & 0.036 & 0.169 & 0.005 & 0.654 \\
\hline $\mathrm{PG}_{4}$ & 0.123 & 0.268 & 0.222 & 0.175 & 0.739 \\
\hline$P_{5}$ & 0.221 & 0.150 & 0.140 & 0.149 & 0.587 \\
\hline
\end{tabular}

Table 2 presents the cross-loadings for each item in the model. Table 2 shows that every item is highly loaded on its construct but not on the other construct therefore cross-loading criteria is satisfied. Therefore, there are no discriminant validity issues. 
Review of Economics and Development Studies, Vol. 6 (4) 2020, 773 - 785

\subsection{The Fornell-Larcker Criterion}

Alternative way to establish discriminant validity is the Fornell-Larker Criterion which implicates condition where the square root of the Average Variance Extracted (AVE) of every construct associates its correlation score with the other latent variable correlations (Fornell \& Larcker, 1981; Hair et al., 2014). Table 3 indicates that discriminant validity through the Fornell-Larcker criterion is also achieved.

\begin{tabular}{|l|l|l|l|l|l|}
\hline \multicolumn{7}{|c|}{ Table 3: Fornell-Larker Criterion } \\
\hline & ATU & CBR & IAGB & MCS & PG \\
\hline ATU & & & & & \\
\hline CBR & 0.671 & & & & \\
\hline IAGB & 0.588 & 0.604 & & & \\
\hline MCS & 0.718 & 0.913 & 0.656 & & \\
\hline PG & 0.412 & 0.626 & 0.586 & 0.517 & \\
\hline
\end{tabular}

As a consequence of establishing discriminant validity, the exploration of the measurement model is completed (Hair et al., 2014). The results of the study reveal that reliability and validity are not only achieved, rather they exceed the set standards for reliability and validity.

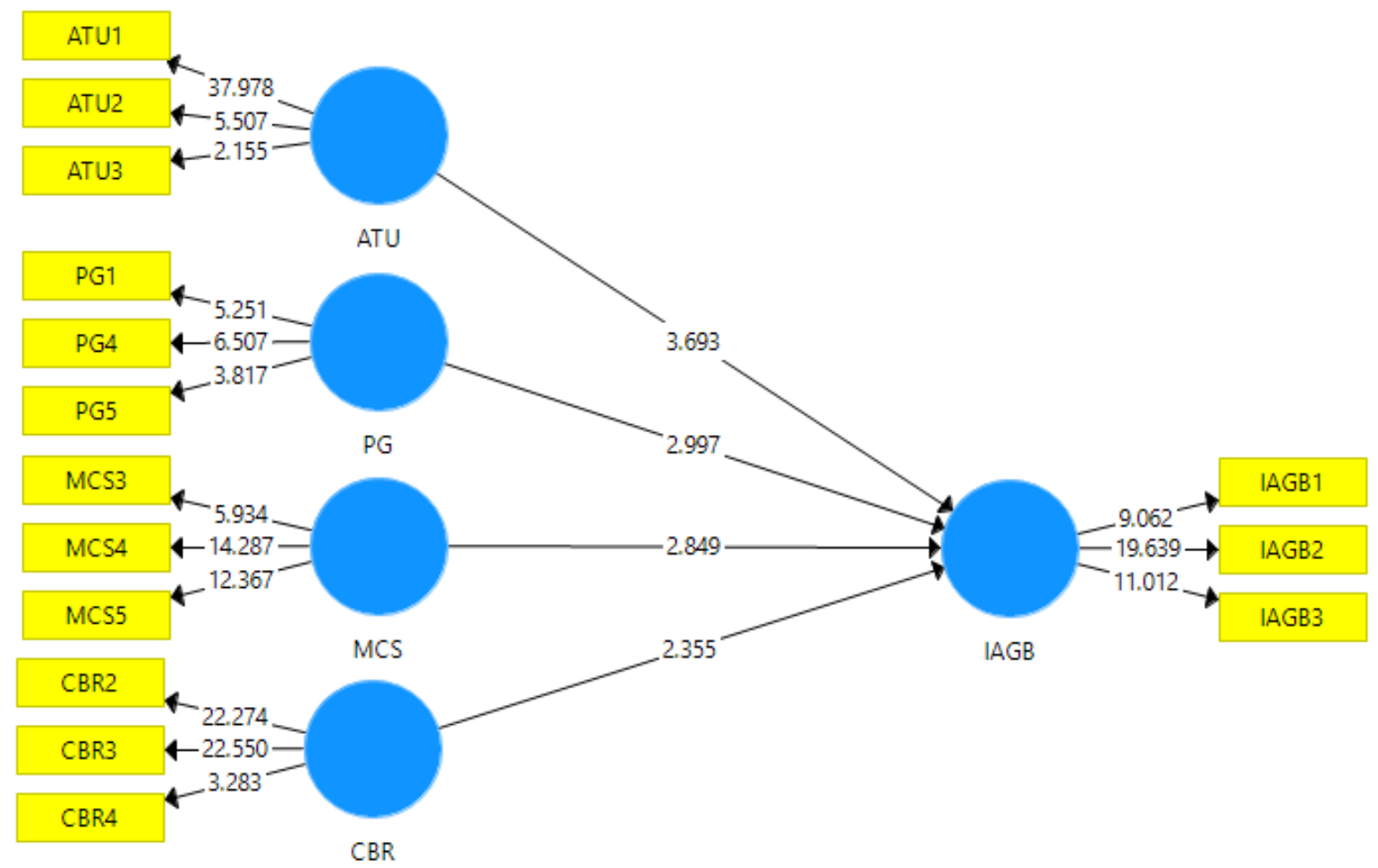

Figure 3: SEM Model Results

The current study has 4 direct hypotheses, as shown in Table 4. All direct hypotheses (H1, H2, $\mathrm{H}_{3}, \mathrm{H}_{4}$ ) were accepted as the t-value was more than 1.96. Hair et al. (2014) explained that PLS is the appropriate techniques to analyse data from a small sample. 
Review of Economics and Development Studies, Vol. 6 (4) 2020, 773 - 785

Table 4: PLS Results

\begin{tabular}{|c|c|c|c|c|c|}
\hline & $\begin{array}{c}\text { Original } \\
\text { Sample (O) }\end{array}$ & $\begin{array}{c}\text { Sample } \\
\text { Mean (M) }\end{array}$ & $\begin{array}{c}\text { Standard Deviation } \\
\text { (STDEV) }\end{array}$ & $\begin{array}{c}\text { T Statistics } \\
\text { (O/STDEV) }\end{array}$ & P Values \\
\hline ATU -> IAGB & 0.218 & 0.226 & 0.059 & 3.693 & $\mathbf{0 . 0 0 0}$ \\
\hline CBR -> IAGB & 0.141 & 0.140 & 0.060 & 2.355 & $\mathbf{0 . 0 1 9}$ \\
\hline MCS -> IAGB & 0.186 & 0.193 & 0.065 & 2.849 & $\mathbf{0 . 0 0 5}$ \\
\hline PG -> IAGB & 0.162 & 0.173 & 0.054 & 2.997 & $\mathbf{0 . 0 0 3}$ \\
\hline
\end{tabular}

\section{Discussion and Conclusion}

The global investment sector has gradually realized its role and responsibility towards environmental degradation. Besides, now a day there is an increase in stakeholders' pressure to adopt environmentally friendly practices on banks. Consequently, a control and remedial strategy was developed in the format of Green Banking. The Green Banking concept was established as a model shift for the banking industry. Based on the present literature, the study proposes that diverse stakeholder pressures can have a positive influence on the adoption of Green Banking. This study also fills the breach in the current Green Banking study by proposing a theoretical context for appraising the determinants for the adoption of Green Banking.

The study's findings indicate that Policy Guidelines, Attitude towards usage, Central Bank Regulations, and Management commitment and support influence bankers' intention to adopt green banking in Pakistan. This research will help the State bank of Pakistan and bank's senior management to identify the key factors influencing the adoption of green banking in Pakistan.

\section{References}

Ahmad, F., Zayed, N. M., \& Harun, A. (2013). Factors behind the Adoption of Green Banking by Bangladeshi Commercial Banks. ASA University Review, 7(2), 241-255. http://www.asaub.edu.bd/data/asaubreview/v7n2sl19.pdf

Aleem, M., \& Bowra, Z. A. (2020). Role of training \& development on employee retention and organizational commitment in the banking sector of Pakistan. Review of Economics and Development Studies, 6(3), 639-650. https://doi.org/10.47067/reads.v6i3.252

Alshibly, H. H. (2011). An extended TAM model to evaluate user's acceptance of electronic cheque clearing systems at jordanian commercial banks. Australian Journal of Basic and Applied Sciences, 5(5), 147-156.

Alwahaishi, S., \& Snášel, V. (2013). Consumers' acceptance and use of information and communications technology: A UTAUT and flow based theoretical model. Journal of Technology Management and Innovation, 8(2), 61-73. https://doi.org/10.4067/so71827242013000200005

Anderson, E. W. (1998). Customer satisfaction and word of mouth. Journal of Service Research, 1(1), 5-17. https://doi.org/10.1177/109467059800100102

Bai, Y. (2011). Financing a Green Future: An examination of China's banking sector for green finance [University of the Aegean (Greece), Central European University (Hungary), Lund University (Sweden) and the University of Manchester (United Kingdom)]. http://lup.lub.lu.se/luur/download?func=downloadFile\&recordOId=2203222\&fileOId=220 322 
Review of Economics and Development Studies, Vol. 6 (4) 2020, $773-785$

Bhardwaj, B. R., \& Malhotra, A. (2013). Green Banking Strategies: Sustainability through Corporate Entrepreneurship. Greener Journal of Business and Management Studies, 3(4), 180-193. https://doi.org/10.1558o/gjbms.2013.4.122412343

Chaudhry, I. S., Azali, M., Faheem, M., \& Ali, S. (2020). Asymmetric Dynamics of Oil Price and Environmental Degradation: Evidence from Pakistan. Review of Economics and Development Studies, 6(1), 1-12. https://doi.org/10.47067/reads.v6i1.179

Chin, W. W., Marcelin, B. L., \& Newsted, P. R. (2003). A partial least squares latent variable modeling approach for measuring interaction effects: Results from a Monte Carlo simulation study and an electronic-mail emotion/adoption study. Information Systems Research, 14(2), 127-219. https://doi.org/10.1287/isre.14.2.189.16018

Fornell, C., \& Larcker, D. F. (1981). Evaluating Structural Equation Models with Unobservable Variables and Measurement Error. Journal of Marketing Research. https://doi.org/10.2307/3151312

Goyal, K. A., \& Joahi, V. (2011). A STUDY OF SOCIAL AND ETHICAL ISSUES IN BANKING INDUSTRY. International Journal of Economics and Research, 2(5), 49-57.

Green Wiki. (2015). Green Banking | Green Wiki | Fandom. https://green.wikia.org/wiki/Green_Banking

Hair, J. F., Black, W. C., Babin, B. J., \& Anderson, R. E. (2014). Multivariate Data Analysis (7th Editio). Pearson Education Limited.

Hossain, D. M., Al Bir, A. T. S., Tarique, K. M., \& Momen, A. (2016). Disclosure of Green Banking Issues in the Annual Reports: A Study on Bangladeshi Banks. Middle East Journal of Business, 11(1), 19-30. https://doi.org/10.5742/mejb.2015.92758

Ifinedo, P. (2011). Internet/e-business technologies acceptance in Canada's SMEs: An exploratory investigation. $\quad$ Internet $\quad$ Research, $21(3), \quad 255^{-281}$ https://doi.org/10.1108/10662241111139309

Khan, M. T. A. (2012, June 5). World Environment Day Special. The Daily Star. http://archive.thedailystar.net/suppliments/2012/environment/pg1.htm

Khan, M. Z. U., Bin Dost, M. K., Akram, M. W., \& Sabri, P. S. U. (2019). Energy Consumption in Agriculture Sector, environmental cleanliness and Economic Growth: An Empirical Evidence of South Asian Countries. Review of Economics and Development Studies, 5(3), 429-436. https://doi.org/10.26710/reads.v5i3.69o

Martín, S. S., López-Catalán, B., \& Ramón-Jerónimo, M. A. (2012). Factors determining firms' perceived performance of mobile commerce. Industrial Management and Data Systems, 112(6), 946-963. https://doi.org/10.1108/02635571211238536

Masood, J., Farooq, F., \& Saeed, M. (2015). CO2 and Environment Change Evidence from Pakistan. Review of Economics and Development Studies, 1(2), 57-72. https://doi.org/10.26710/reads.v1i2.116

Masukujjaman, M., \& Aktar, S. (2014). Green Banking in Bangladesh: A Commitment towards the Global Initiatives. Journal of Business and Technology (Dhaka), 8(1-2), 17-40. https://doi.org/10.3329/jbt.v8i1-2.18284

Millat, K. M., Chowdhury, R., \& Singha, E. A. (2012). Green Banking in Bangladesh: Fostering Environmentally Sustainable Inclusive Growth Process. Bangladesh Bank. http://www.bangladesh-bank.org/pub/special/greenbankingbd.pdf

Munchow, S. T. (2011). Geschäftspolitik von ethisch respektive sozial orientierten Banken im Vergleich $\mathrm{zu}$ herkömmlichen renditeorientierten Banken. https://www.grin.com/document/184405

Nath, V., Nayak, N., \& Goel, A. (2014). GREEN BANKING PRACTICES - A REVIEW. International Journal of Research in Business Management, 2(4), 45-62. 
Review of Economics and Development Studies, Vol. 6 (4) 2020, $773-785$

http://oaji.net/articles/2014/490-13999666o2.pdf

Parveen, S., Ali, H., Sahibzada, H. E., \& Farooq, S. (2020). A Causal Nexus of Energy Consumption, Private Investment, Economic Growth and Environmental Degradation: Evidence from Pakistan. Review of Economics and Development Studies, 6(2), 267-276. https://doi.org/10.47067/reads.v6i2.204

Parveen, S., Khan, A. Q., \& Farooq, S. (2019). The Causal Nexus of Urbanization, Industrialization, Economic Growth and Environmental Degradation: Evidence From Pakistan. Review of $\begin{array}{llll}\text { Economics and Development } & \text { 721-730. }\end{array}$ https://doi.org/10.26710/reads.v5i4.883

Rahman, M. M., Ahsan, M. A., Hossain, M. M., \& Hoq, M. R. (2013). Green Banking Prospects in Bangladesh. Asian Business Review. https://doi.org/10.18034/abr.v2i2.112

Raluca, D. O. (2013). Pathways to Sustainable Banking Management. The Journal of the Faculty of Economics, 1(2), 545-550.

Ramdani, B., Kawalek, P., \& Lorenzo, O. (2009). Predicting SMEs' adoption of enterprise systems. Journal of Enterprise Information Management, 22(1-2), 10-24. https://doi.org/10.1108/17410390910922796

Rehman, A. (2015). Bangladesh Bank Governor Speech on Socially Responsible Financing.

Rosenfeld, E., \& Tchapi, P. D. T. (2007). Environmental Concerns and Banking Sector in Sweden [University of Skövde]. http://his.diva-portal.org/smash/get/diva2:2178/FULLTEXTo1.pdf

Starogiannis, D. (2006). What is the Environmental Responsibility of Banks? UNEP FI Conference 22-6-o6. http://www.unepfi.org/fileadmin/events/20o6/athens/7_starogiannis.pdf

Thombre, K. A. (2011). The New Face of Banking: Green Banking. Golden Research Thoughts, 1(1), $1-4$.

Ullah, M. M. (2013). World Review of Business Research Green Banking in Bangladesh- A Comparative Analysis Ullah. World Review of Business Research, 3(4), 74-83. 